\title{
Coronary heart disease: a disorder of growth
}

\author{
S. M. Robinson and D. J. P. Barker* \\ MRC Environmental Epidemiology Unit, University of Southampton, Southampton General Hospital, \\ Southampton SO16 6YD, UK
}

\begin{abstract}
The search for the causes of CHD has been guided by a 'destructive' model, which proposes that influences acting in adult life, such as smoking, obesity or high saturated fat intakes, lead to an acceleration of age-related destructive processes, including a rise in blood pressure and the formation of atheroma. One explanation for the failure of the model to account for, or indeed to prevent rising epidemics of CHD, is that individuals are heterogeneous in their responses to such influences. This heterogeneity in response is linked to different paths of early growth. The recent discovery that individuals who develop CHD grew differently from other individuals during fetal life and in childhood has led to a new 'developmental' model for the disease. Reduced fetal growth followed by poor growth in infancy leads to an increased risk of development of CHD, and its associated conditions, stroke, hypertension and impaired glucose tolerance. These effects are compounded by accelerated weight gain, which may represent 'compensatory growth' in childhood.
\end{abstract}

\section{CHD: Fetal programming: Fetal growth: Childhood growth}

The search for the causes of CHD, and the way to prevent it, has been guided by a 'destructive' model. The principal causes to be identified are thought to act in adult life and to accelerate destructive processes, e.g. the formation of atheroma, rise in blood pressure and loss of glucose tolerance, which accompany ageing. This model, however, has had limited success. Obesity, diets high in saturated fat, cigarette smoking and psycho-social stress have all been implicated. The effects of modifying adult lifestyle, when formally tested in randomised trials have, however, been disappointingly small (Ebrahim \& Davey Smith, 1997; Hooper et al. 2001). The model has proved incapable of answering important questions. For example, in Western countries the steep increase in the disease has been associated with rising prosperity, so why do the poorest individuals in the poorest places have the highest rates (Acheson, 1998)?

One explanation for our failure to understand and to prevent rising epidemics of CHD is that individuals are heterogeneous in their responses to environmental influences. Smoking, for example, is harmful to some individuals but less harmful to others. Some statisticians argue that we therefore need much larger studies to overcome this, while geneticists argue that the heterogeneity results from genes as yet unknown. There is, however, another way forward, which is to examine the biological basis of the differences between individuals. The recent discovery that individuals who develop CHD grew differently from other individuals during fetal life and childhood encourages this view (Eriksson et al. 2001), and has led to a new 'developmental' model for the disease (Barker, 1995, 1998).

\section{Growth and CHD}

Fig. 1 shows the growth of 357 men who were either admitted to hospital with CHD or who died from it (Eriksson et al. 2001), from a cohort of 4630 men who were born in and who grew up in Helsinki, Finland. Their growth is expressed as Z-scores. The Z-score for the cohort is set at zero, and a boy maintaining a steady position as large or small in relation to other boys would follow a horizontal path on the figure. Boys who later developed CHD were small at birth. They remained small in infancy, but had accelerated gain in weight and BMI thereafter. In contrast, their heights remained below average. Table 1 shows the hazard ratios for CHD according to size at birth. The hazard ratios fall with increasing birth weight and, more strongly, with increasing ponderal index (birth weight/length ${ }^{3}$ ), a measure of thinness at birth. These trends were found in babies born at term and in those born prematurely, and 


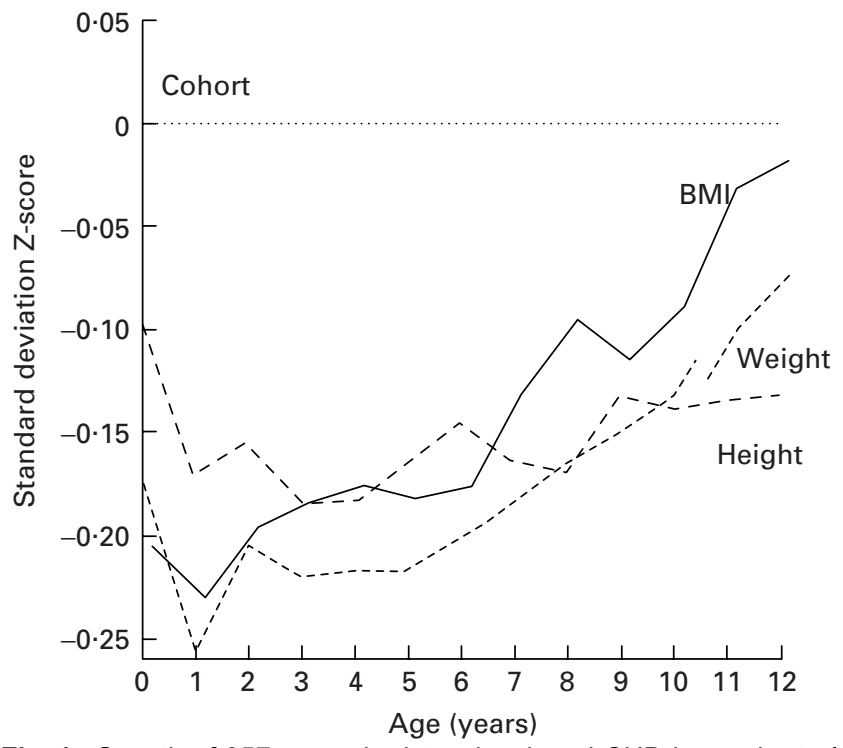

Fig. 1. Growth of 357 men who later developed $\mathrm{CHD}$ in a cohort of 4630 men born in Helsinki, Finland. (-), BMI; (- -), height; (----), weight; $(\cdots \cdots)$, SD (Z)-score for the cohort is set at zero. (From Eriksson et al. 2001.)

Table 1. Hazard ratios for CHD according to body size at birth for men born in Helsinki, Finland (from Eriksson et al. 2001) (Values are hazard ratios and $95 \% \mathrm{Cl}$ )

\begin{tabular}{|c|c|c|c|c|}
\hline & $\begin{array}{l}\text { Hazard } \\
\text { ratios }\end{array}$ & $\begin{array}{c}95 \% \\
\mathrm{Cl}\end{array}$ & $\begin{array}{l}\text { No. of } \\
\text { cases }\end{array}$ & $\begin{array}{c}\text { No. of } \\
\text { men }\end{array}$ \\
\hline \multicolumn{5}{|c|}{ Birth weight $(\mathrm{g})$ : } \\
\hline$\leq 2500$ & $3 \cdot 63$ & $2 \cdot 02,6 \cdot 51$ & 24 & 160 \\
\hline $2501-3000$ & $1 \cdot 83$ & $1.09,3.07$ & 45 & 599 \\
\hline $3001-3500$ & 1.99 & $1 \cdot 26,3 \cdot 15$ & 144 & 1775 \\
\hline $3501-4000$ & $2 \cdot 08$ & $1 \cdot 31,3 \cdot 31$ & 123 & 1558 \\
\hline$>4000$ & 1.00 & & 21 & 538 \\
\hline For trend: $P$ & \multicolumn{2}{|c|}{0.006} & & \\
\hline \multicolumn{5}{|c|}{ Ponderal index $\left(\mathrm{kg} / \mathrm{m}^{3}\right)$ : } \\
\hline$\leq 25$ & 1.66 & $1 \cdot 11,2 \cdot 48$ & 104 & 1093 \\
\hline $25-27$ & 1.44 & $0.97,2 \cdot 13$ & 135 & 1643 \\
\hline $27-29$ & $1 \cdot 18$ & $0 \cdot 78,1 \cdot 78$ & 84 & 1260 \\
\hline$>29$ & $1 \cdot 00$ & & 31 & 578 \\
\hline For trend: $P$ & \multicolumn{2}{|c|}{0.0006} & & \\
\hline
\end{tabular}

therefore reflect slow intra-uterine growth. Table 2 shows that the hazard ratios also fall with increasing weight, height and BMI at age 1 year. Small size at this age predicts CHD independently of size at birth (Eriksson et al. 2001). In a simultaneous analysis with birth weight the hazard ratio associated with each unit decrease in Z-score for weight between birth and 1 year is $1.21(1.08,1.3695 \% \mathrm{CI}$, $P=0 \cdot 001$ ).

The association between CHD and small size at birth has been shown in studies in Europe (Barker et al. 1989; Frankel et al. 1996; Leon et al. 1998), North America (RichEdwards et al. 1997) and India (Stein et al. 1996). The association with poor weight gain in infancy was first shown in Hertfordshire (Barker et al. 1989), and confirmed in
Table 2. Hazard ratios for $\mathrm{CHD}$ according to body size at 1 year for men born and in Helsinki, Finland (From Eriksson et al. 2001) (Values are hazard ratios and $95 \% \mathrm{Cl}$ )

\begin{tabular}{|c|c|c|c|c|}
\hline & $\begin{array}{l}\text { Hazard } \\
\text { ratios }\end{array}$ & $\begin{array}{c}95 \% \\
\mathrm{Cl}\end{array}$ & $\begin{array}{l}\text { No. of } \\
\text { cases }\end{array}$ & $\begin{array}{c}\text { No. of } \\
\text { men }\end{array}$ \\
\hline Weight (kg): $\leq 9$ & $1 \cdot 82$ & $1 \cdot 25,2 \cdot 64$ & 96 & 781 \\
\hline $9-10$ & $1 \cdot 17$ & $0 \cdot 80,1 \cdot 71$ & 85 & 1126 \\
\hline 10-11 & $1 \cdot 12$ & $0 \cdot 77,1.64$ & 89 & 1243 \\
\hline $11-12$ & 0.94 & $0 \cdot 62,1 \cdot 44$ & 49 & 852 \\
\hline$>12$ & $1 \cdot 00$ & & 38 & 619 \\
\hline For trend: $P$ & \multicolumn{2}{|c|}{$<0.0001$} & & \\
\hline Height $(m): \leq 0 \cdot 73$ & 1.55 & $1 \cdot 11,2 \cdot 18$ & 79 & 636 \\
\hline $0.73-0.75$ & 0.90 & $0.63,1.27$ & 68 & 962 \\
\hline $0 \cdot 75-0 \cdot 77$ & 0.94 & $0 \cdot 68,1 \cdot 31$ & 87 & 1210 \\
\hline $0.77-0.79$ & 0.83 & $0 \cdot 58,1 \cdot 18$ & 64 & 1011 \\
\hline$>0 \cdot 79$ & $1 \cdot 00$ & & 59 & 802 \\
\hline For trend: $P$ & \multicolumn{2}{|c|}{0.007} & & \\
\hline BMI $\left(\mathrm{kg} / \mathrm{m}^{2}\right):<16$ & $1 \cdot 83$ & $1 \cdot 28,2 \cdot 60$ & 72 & 654 \\
\hline $16-17$ & $1 \cdot 61$ & $1 \cdot 15,2 \cdot 25$ & 89 & 936 \\
\hline $17-18$ & $1 \cdot 29$ & $0.91,1 \cdot 81$ & 83 & 1136 \\
\hline $18-19$ & $1 \cdot 12$ & $0.77,1.62$ & 59 & 941 \\
\hline$>19$ & 1.00 & & 54 & 954 \\
\hline For trend: $P$ & \multicolumn{2}{|c|}{$<0.0004$} & & \\
\hline
\end{tabular}

Helsinki (Eriksson et al. 2001); the strength of the association being similar in the two studies. The association between CHD and rapid childhood weight gain was first shown in a study of an older cohort of men born in Helsinki (Eriksson et al. 1999), while the association with low rates of height growth is consistent with the known association between the disease and short adult stature in men (Marmot et al. 1984).

Fig. 2, based on the same data as that used in Fig. 1 shows the combined effects of ponderal index at birth and BMI in childhood on hazard ratios for CHD in the Helsinki cohort (Eriksson et al. 2001). The lines shown in Fig. 2 join points with the same hazard ratios. For example, the line for the highest ratio, $1 \cdot 75$, is associated with low ponderal index at birth but above average BMI in childhood. Boys who had a low ponderal index at birth increased their risk of CHD if they attained even average BMI in childhood. In contrast, among boys with a high ponderal index at birth, no increased risk was associated with a high childhood BMI. The interaction between ponderal index at birth and BMI in childhood is strongly statistically significant $(P<0 \cdot 001)$. Findings among girls are similar (Forsen et al. 1999), and again the risk of CHD is determined more by the tempo of weight gain in childhood than the body size attained.

\section{Growth and hypertension and type $\mathbf{2}$ diabetes}

There is now a substantial body of evidence showing that individuals who were small at birth remain biologically different from individuals who were larger. The differences include an increased susceptibility to hypertension and type 2 diabetes in adult life, two disorders closely linked to CHD (Hales et al. 1991; Curhan et al. 1996; Eriksson et al. 2000; Forsen et al. 2000). Table 3 shows the odds ratios for 
hypertension and type 2 diabetes among 13517 men and women from two Helsinki cohorts combined (Eriksson et al. 2000; Forsen et al. 2000; Barker et al. 2002) according to weight at birth and BMI at age 11 years. These two disorders are associated with the same general pattern of growth as CHD. The highest risk for each disease occurs among men and women who had low birth weight but who were in the highest BMI group at 11 years. Similarly to $\mathrm{CHD}$, the risk of disease is not determined only by the absolute value of BMI in childhood, but by the combination

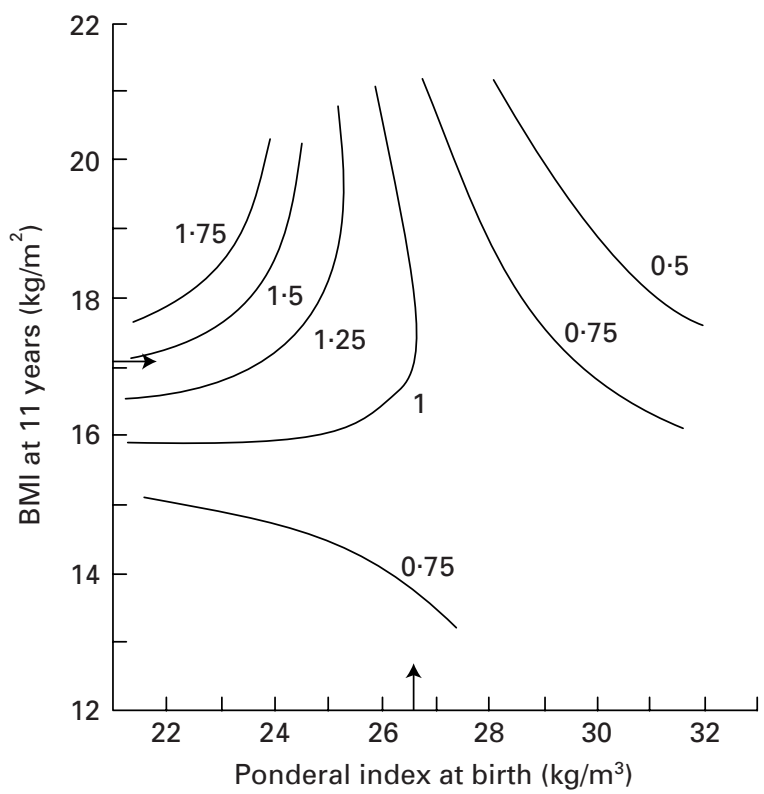

Fig. 2. Hazard ratios for $\mathrm{CHD}$ according to ponderal index (weight/length ${ }^{3}$ ) at birth and BMI $\left(\mathrm{kg} / \mathrm{m}^{2}\right)$ at 11 years for men born in Helsinki, Finland. $(\rightarrow)$, Average values; $(-)$, joins points with the same hazard ratios. (From Eriksson et al. 2001.) of body size at birth and during childhood (Eriksson et al. 2000; Forsen et al. 2000). It is the tempo of growth as well as the attained body size that determine risk.

The associations between slow fetal and infant growth and later CHD are strong and graded. In the Helsinki cohort boys who at birth had a ponderal index $>26 \mathrm{~kg} / \mathrm{m}^{3}$ and who at 1 year of age were above the cohort average for BMI $\left(17 \cdot 7 \mathrm{~kg} / \mathrm{m}^{2}\right)$ and height $(0.762 \mathrm{~m})$ were at half the risk of developing CHD before the age of 65 years (Eriksson et al. 2001). This finding, together with the data on hypertension and type 2 diabetes (Table 3 ) confirms the strong effects of early growth on disease.

\section{Biological mechanisms}

The associations between altered growth and CHD suggest that the disease may originate in two phenomena associated with development, 'phenotypic plasticity' and 'compensatory growth'. Phenotypic plasticity is the phenomenon whereby one genotype gives rise to a range of different physiological or morphological states in response to different environmental conditions during development (West-Eberhard, 1989; Bateson \& Martin, 1999). Such gene-environment interactions are ubiquitous in development. Their existence is demonstrated by the numerous experiments showing that minor alterations to the diets of pregnant animals, which may not even change body size at birth, can produce lasting changes in the offspring's physiology and metabolism, including altered blood pressure and glucose-insulin and lipid metabolism (Desai \& Hales, 1997; Kwong et al. 2000). The evolutionary benefit of phenotypic plasticity is that, in a changing environment, it enables the production of phenotypes that are better matched to their environment than would be possible if one genotype produced the same phenotype in all environments (West-Eberhard, 1989). When undernutrition during devel-

Table 3. Odds ratios $(\mathrm{OR})^{\star}$ for type 2 diabetes and hypertension according to birth weight and BMI at 11 years for 13517 men and women from two Helsinki, Finland cohorts born 1924-44 (from Barker et al. 2002)

(Values are OR and $95 \% \mathrm{Cl}$ )

\begin{tabular}{|c|c|c|c|c|c|c|c|c|c|}
\hline & \multirow[b]{3}{*}{ Birth weight (kg) } & \multicolumn{8}{|c|}{ BMl at 11 years $\left(\mathrm{kg} / \mathrm{m}^{2}\right)$} \\
\hline & & \multicolumn{2}{|c|}{$\leq 15 \cdot 7$} & \multicolumn{2}{|c|}{$15 \cdot 7-16 \cdot 6$} & \multicolumn{2}{|c|}{$16 \cdot 7-17 \cdot 6$} & \multicolumn{2}{|c|}{$>17 \cdot 6$} \\
\hline & & OR & $95 \% \mathrm{Cl}$ & OR & $95 \% \mathrm{Cl}$ & OR & $95 \% \mathrm{Cl}$ & OR & $95 \% \mathrm{Cl}$ \\
\hline \multirow[t]{4}{*}{ No. of men and women } & $\leq 3.0$ & \multicolumn{2}{|c|}{991} & \multicolumn{2}{|c|}{719} & \multicolumn{2}{|c|}{581} & \multicolumn{2}{|c|}{560} \\
\hline & $3 \cdot 0-3 \cdot 5$ & \multicolumn{2}{|c|}{1394} & \multicolumn{2}{|c|}{1422} & \multicolumn{2}{|c|}{1264} & \multicolumn{2}{|c|}{1246} \\
\hline & $3 \cdot 5-4 \cdot 0$ & \multicolumn{2}{|c|}{827} & \multicolumn{2}{|c|}{984} & \multicolumn{2}{|c|}{1122} & \multicolumn{2}{|c|}{1110} \\
\hline & $>4 \cdot 0$ & \multicolumn{2}{|c|}{167} & \multicolumn{2}{|c|}{254} & \multicolumn{2}{|c|}{413} & \multicolumn{2}{|c|}{463} \\
\hline \multirow[t]{4}{*}{ Type 2 diabetes (698 cases) } & $\leq 3 \cdot 0$ & $1 \cdot 3$ & $0 \cdot 6,2 \cdot 8$ & $1 \cdot 3$ & $0 \cdot 6,2 \cdot 8$ & $1 \cdot 5$ & $0 \cdot 7,3 \cdot 4$ & $2 \cdot 5$ & $1 \cdot 2,5 \cdot 5$ \\
\hline & $3 \cdot 0-3 \cdot 5$ & $1 \cdot 0$ & $0 \cdot 5,2 \cdot 1$ & $1 \cdot 0$ & $0 \cdot 5,2 \cdot 1$ & $1 \cdot 5$ & $0 \cdot 7,3 \cdot 2$ & $1 \cdot 7$ & $0 \cdot 8,3 \cdot 5$ \\
\hline & $3 \cdot 5-4 \cdot 0$ & $1 \cdot 0$ & $0.5,2 \cdot 2$ & 0.9 & $0.4,1.9$ & 0.9 & $0 \cdot 4,2 \cdot 0$ & $1 \cdot 7$ & $0 \cdot 8,3 \cdot 6$ \\
\hline & $>4 \cdot 0$ & $1 \cdot 0$ & & $1 \cdot 1$ & $0 \cdot 4,2 \cdot 7$ & $0 \cdot 7$ & $0 \cdot 3,1 \cdot 7$ & $1 \cdot 2$ & $0 \cdot 5,2 \cdot 7$ \\
\hline \multirow[t]{4}{*}{ Hypertension (2997 cases) } & $\leq 3.0$ & $2 \cdot 0$ & $1 \cdot 3,3 \cdot 2$ & $1 \cdot 9$ & $1 \cdot 2,3 \cdot 1$ & 1.9 & $1 \cdot 2,3 \cdot 0$ & $2 \cdot 3$ & $1 \cdot 5,3 \cdot 8$ \\
\hline & $3.0-3.5$ & $1 \cdot 7$ & $1 \cdot 1,2 \cdot 6$ & 1.9 & $1 \cdot 2,2 \cdot 9$ & 1.9 & $1 \cdot 2,3 \cdot 0$ & $2 \cdot 2$ & $1 \cdot 4,3 \cdot 4$ \\
\hline & $3 \cdot 5-4 \cdot 0$ & $1 \cdot 7$ & $1 \cdot 0,2 \cdot 6$ & $1 \cdot 7$ & $1 \cdot 1,2 \cdot 6$ & 1.5 & $1 \cdot 0,2 \cdot 4$ & 1.9 & $1 \cdot 2,2 \cdot 9$ \\
\hline & $>4 \cdot 0$ & $1 \cdot 0$ & & 1.9 & $1 \cdot 1,3 \cdot 1$ & $1 \cdot 0$ & $0 \cdot 6,1 \cdot 7$ & $1 \cdot 7$ & $1 \cdot 1,2 \cdot 8$ \\
\hline
\end{tabular}

${ }^{*}$ Adjusted for gender and year of birth. 
opment is followed by improved nutrition, many animals stage accelerated or 'compensatory' growth in weight or length. This growth restores the animal's body size but may have long-term costs, which include a reduced lifespan (Metcalfe \& Monaghan, 2001).

There are several possible mechanisms by which reduced fetal and infant growth followed by accelerated weight gain in childhood may lead to CHD. Babies who are thin at birth lack muscle, a deficiency that will persist as the critical period for muscle growth is around 30 weeks in utero, and there is little cell replication after birth (Widdowson et al. 1972). If they develop a high BMI in childhood they may have a disproportionately high fat mass. This situation may be associated with the development of insulin resistance, since children and adults who had low birth weight but are currently heavy are insulin resistant (Barker et al. 1993; Lithell et al. 1996; Bavdekar et al. 1999).

Small babies have reduced numbers of nephrons (MerletBenichou et al. 1993; Brenner \& Chertow, 1994). It has been suggested that this leads to hyperperfusion of each nephron and resulting glomerular sclerosis, further nephron death and a cycle of increasing blood pressure and nephron death. This process may be exacerbated if accelerated growth increases the degree of hyperperfusion. This framework fits with the hypothesis that essential hypertension is a disorder of growth involving two separate mechanisms, a growth-promoting process in childhood and a self-perpetuating mechanism in adult life (Lever \& Harrap, 1992). The existence of such self-perpetuating cycles, initiated in utero, but triggered by ageing or other influences in later life, would explain the small effects of birth size on blood pressure levels in the normal population (Huxley et al. 2000), but its large effects on the risk of hypertension.

\section{Responses to adult living standards}

Observations on animals show that the environment during development permanently changes not only the body's structure and function, but also its responses to environmental influences encountered in later life (Bateson \& Martin, 1999). Men who had low birth weight are more vulnerable to developing CHD and type 2 diabetes if they become overweight (Frankel et al. 1996; Lithell et al. 1996). Table 4 shows the effect of low income in adult life on CHD among men in Helsinki (Barker et al. 2001). As expected, men who had a low taxable income had higher rates of the disease (Marmot \& McDowell, 1986; Acheson, 1998; Macintyre et al. 2001). There is no known explanation for this relationship, and it is a major component of the social inequalities in health in Western countries. The effect of low income, however, is confined to men who had slow fetal growth and who were thin at birth, defined by a ponderal index $<26 \mathrm{~kg} / \mathrm{m}^{3}$. Men who were not thin at birth were resilient to the effects of low income on $\mathrm{CHD}$, so that there was a statistically significant interaction between the effects of fetal growth and adult income $(P=0 \cdot 005)$.

One explanation of these findings emphasises the psycho-social consequences of a low position in the social hierarchy, as indicated by low income and social class, and suggests that perceptions of low social status and lack of success lead to changes in neuroendocrine pathways and hence to disease (Marmot \& Wilkinson, 2001). The findings from Helsinki (Barker et al. 2001) seem consistent with this explanation. Individuals who are small at birth are known to have persisting alterations in responses to stress, including raised serum cortisol concentrations (Phillips et al. 2000). Rapid childhood weight gain could exacerbate these effects.

\section{Mothers and babies today}

The principal determinant of growth rates in early life is the availability of nutrition. As yet we do not know the impact of maternal nutrition on fetal development (Godfrey $\&$ Barker, 2001). The relatively disappointing effects of dietary interventions in pregnancy on birth weight in human subjects have led to the view that fetal nutrition is little affected by maternal nutrition (Harding, 2001). It is becoming clear, however, that the concept of maternal nutrition must be extended beyond the mother's diet in pregnancy to include her body composition and metabolism both during pregnancy and at the time of conception (Jackson \& Robinson, 2001). Moreover, birth weight is an inadequate description of those phenotypic characteristics of a baby that determine its long-term health (Barker, 1998; Ravelli et al. 1998). As birth weight and ponderal index are crude measures of how fetal nutrition has affected body composition, the true size of the effect of fetal growth on later disease is hard to measure (Robinson, 2001), and we therefore need a more sophisticated view of optimal fetal development that takes account of the long-term sequelae of fetal responses to undernutrition. If we are to protect babies, we must also protect girls in childhood and adolescence. Body composition is established by childhood growth and obesity, and eating habits that are entrained during childhood and adolescence (Dietz, 1996). Given the body of evidence showing that $\mathrm{CHD}$, and the related disorders stroke, hypertension and type 2 diabetes, originate through undernutrition and other adverse influences in utero, followed by accelerated weight gain thereafter, protecting the nutrition and health of young women and their babies must be part of any effective strategy for preventing these diseases.

As Westernisation improves the nutrition of undernourished populations, fetal nutrition improves more slowly than nutrition during childhood or adult life, because the fetus is linked to its mother by a long and precarious supply line that is partly established during the mother's fetal life. It may require more than one generation of improved nutrition before fetal growth responds, whereas child growth responds in one generation. During this phase of development children who were small at birth undergo accelerated, compensatory growth. This is the path of growth that leads to CHD and, it seems, may generate the epidemics of the disease (Fig. 1). Through phenotypic plasticity and the costs of compensatory growth, individuals who follow this path are permanently biologically different and at increased risk of CHD. They are also more vulnerable to the effects of poor living standards (Table 4), obesity and other adverse influences in adult life. 
Table 4. Hazard ratios for CHD according to ponderal index at birth $\left(\mathrm{kg} / \mathrm{m}^{3}\right)$ and taxable income in adult life for men born and in Helsinki, Finland (from Barker et al. 2001)

(Values are hazard ratios and $95 \% \mathrm{Cl}$ )

\begin{tabular}{|c|c|c|c|c|c|}
\hline \multicolumn{2}{|c|}{ Household income } & \multicolumn{2}{|c|}{ Ponderal index $\leq 26 \cdot 0(n$ 1475) } & \multicolumn{2}{|c|}{ Ponderal index $>26 \cdot 0(n$ 2154) } \\
\hline $10^{3}$ mark/year & $£ /$ year & Hazard ratio & $95 \% \mathrm{Cl}$ & Hazard ratio & $95 \% \mathrm{Cl}$ \\
\hline$>140$ & 15700 & $1 \cdot 00$ & & $1 \cdot 19$ & $0 \cdot 65,2 \cdot 19$ \\
\hline $111-140$ & 15700 & $1 \cdot 54$ & $0 \cdot 83,2 \cdot 87$ & $1 \cdot 42$ & $0.78,2.57$ \\
\hline $96-110$ & 12400 & $1 \cdot 07$ & $0 \cdot 51,2 \cdot 22$ & $1 \cdot 66$ & $0.90,3.07$ \\
\hline $76-95$ & 10700 & $2 \cdot 07$ & $1 \cdot 13,3 \cdot 79$ & $1 \cdot 44$ & $0.79,2.62$ \\
\hline$\leq 75$ & 8400 & 2.58 & $1 \cdot 45,4 \cdot 60$ & $1 \cdot 37$ & $0.75,2.51$ \\
\hline For trend: $P$ & & $<0.0001$ & & $0 \cdot 75$ & \\
\hline
\end{tabular}

\section{Conclusion}

The effect of a high body mass in childhood on risk of CHD, and related disorders, is conditioned by size at birth (Fig. 2). The effect of poor living standards in adult life is also conditioned by size at birth (Table 4). The effects of any single influence therefore depend on the path of development that preceded it, and the pathogenesis of CHD or type 2 diabetes cannot be understood within a model in which risks associated with adverse influences at different stages of life add to each other (Kuh \& Ben-Shlomo, 1997). Rather, the consequences of adverse influences depend on events at earlier critical stages of development (Eriksson et al. 2001). This embodies the concept of developmental 'switches' triggered by the environment (Bateson \& Martin, 1999). The effects of any particular birth weight on disease will not only depend on the subsequent path of development, but also on the path of growth that led to that birth weight. The same weight can be attained by many different paths of fetal growth, and each path is likely to be accompanied by different gene-environment interactions, although this remains to be demonstrated (Harding, 2001).

\section{References}

Acheson D (1998) Independent Inquiry into Inequalities in Health. London: H. M. Stationery Office.

Barker DJP (1995) Fetal origins of coronary heart disease. British Medical Journal 311, 171-174.

Barker DJP (1998) Mothers, Babies and Health in Later Life, 2nd ed. Edinburgh: Churchill Livingstone.

Barker DJP, Eriksson JG, Forsen T \& Osmond C (2002) Fetal origins of adult disease: strength of effects and biological basis. International Journal of Epidemiology (In the Press).

Barker DJP, Forsen T, Uutela A, Osmond C \& Eriksson JG (2001) Size at birth and resilience to the effects of poor living conditions in adult life: longitudinal study. British Medical Journal 323, 1273-1276.

Barker DJP, Hales CN, Fall CHD, Osmond C, Phipps K \& Clark PMS (1993) Type 2 (non-insulin-dependent) diabetes mellitus, hypertension and hyperlipidaemia (syndrome $\mathrm{X}$ ): relation to reduced fetal growth. Diabetologia 36, 62-67.

Barker DJP, Osmond C, Winter PD, Margetts B \& Simmonds SJ (1989) Weight in infancy and death from ischaemic heart disease. Lancet ii, 577-580.

Bateson P \& Martin P (1999) Design for a Life: How Behaviour Develops. London: Jonathan Cape.

Bavdekar A, Chittaranjan S, Fall CHD, Bapat S, Pandit AN, Deshpande V, Bhave S, Kellingray SD \& Joglekar C (1999)
Insulin resistance syndrome in 8 -year-old Indian children. Small at birth, big at 8 years, or both? Diabetes 48, 2422-2429.

Brenner BM \& Chertow GM (1994) Congenital oligonephropathy and the etiology of adult hypertension and progressive renal injury. American Journal of Kidney Diseases 23, 171-175.

Curhan GC, Chertow GM, Willett WC, Spiegelman D, Colditz GA, Manson JE, Speizer FE \& Stampfer MJ (1996) Birth weight and adult hypertension and obesity in women. Circulation 94, $1310-1315$.

Desai M \& Hales CN (1997) Role of fetal and infant growth in programming metabolism in later life. Biological Reviews of the Cambridge Philosophical Society 72, 329-348.

Dietz WH (1996) Early influences on body weight regulation. In Regulation of Body Weight: Biological and Behavioral Mechanisms, pp. 149-156 [C Bouchard and GA Bray, editors]. Chichester, West Sussex: John Wiley.

Ebrahim S \& Davey Smith G (1997) Systematic review of randomised controlled trials of multiple risk factor interventions for preventing coronary heart disease. British Medical Journal 314, 1666-1674.

Eriksson JG, Forsen T, Tuomilehto J, Osmond C \& Barker DJP (2000) Fetal and childhood growth and hypertension in adult life. Hypertension 36, 790-794.

Eriksson JG, Forsen T, Tuomilehto J, Osmond C \& Barker DJP (2001) Early growth and coronary heart disease in later life: longitudinal study. British Medical Journal 322, 949-953.

Eriksson JG, Forsen T, Tuomilehto J, Winter PD, Osmond C \& Barker DJP (1999) Catch-up growth in childhood and death from coronary heart disease: longitudinal study. British Medical Journal 318, 427-431.

Forsen T, Eriksson JG, Tuomilehto J, Osmond C \& Barker DJP (1999) Growth in utero and during childhood among women who develop coronary heart disease: longitudinal study. British Medical Journal 319, 1403-1407.

Forsen T, Eriksson J, Tuomilehto J, Reunanen A, Osmond C \& Barker D (2000) The fetal and childhood growth of persons who develop type 2 diabetes. Annals of Internal Medicine 133, 176-182.

Frankel S, Elwood P, Sweetnam P, Yarnell J \& Davey Smith G (1996) Birthweight, body-mass index in middle age, and incident coronary heart disease. Lancet 348, 1478-1480.

Godfrey KM \& Barker DJP (2001) Fetal programming and adult health. Public Health Nutrition 4, 611-624.

Hales CN, Barker DJP, Clark PMS, Cox LJ, Fall C, Osmond C \& Winter PD (1991) Fetal and infant growth and impaired glucose tolerance at age 64. British Medical Journal 303, $1019-1022$.

Harding JE (2001) The nutritional basis of the fetal origins of adult disease. International Journal of Epidemiology 30, 15-23.

Hooper L, Summerbell CD, Higgins JPT, Thompson RL, Capps NE, Davey Smith G, Riemersma RA \& Ebrahim S (2001) 
Dietary fat intake and prevention of cardiovascular disease: systematic review. British Medical Journal 322, 757-763.

Huxley RR, Shiell AW \& Law CM (2000) The role of size at birth and postnatal catch-up growth in determining systolic blood pressure: a systematic review of the literature. Journal of Hypertension 18, 815-831.

Jackson AA \& Robinson SM (2001) Dietary guidelines for pregnancy: a review of current evidence. Public Health Nutrition 4, 625-630.

Kuh D \& Ben-Shlomo Y (1997) A Life-course Approach to Chronic Disease Epidemiology. Oxford: Oxford University Press

Kwong WY, Wild A, Roberts P, Willis AC \& Fleming TP (2000) Maternal undernutrition during the preimplantation period of rat development causes blastocyst abnormalities and programming of postnatal hypertension. Development 127, 4195-4202.

Leon D, Lithell HO, Vagero D, Koupilova I, Mohsen R, Berglund L, Lithell UB \& McKeigue P (1998) Reduced fetal growth rate and increased risk of death from ischaemic heart disease: cohort study of 15000 Swedish men and women born 1915-29. British Medical Journal 317, 241-245.

Lever AF \& Harrap SB (1992) Essential hypertension: a disorder of growth with origins in childhood? Journal of Hypertension $\mathbf{1 0}$, 101-120.

Lithell HO, McKeigue PM, Berglund L, Mohsen R, Lithell UB \& Leon DA (1996) Relation of size at birth to non-insulin dependent diabetes and insulin concentrations in men aged 50-60 years. British Medical Journal 312, 406-410.

Macintyre K, Stewart S, Chalmers J, Pell J, Finlayson A, Boyd J, Redpath A, McMurray J \& Capewell S (2001) Relation between socio-economic deprivation and death from a first myocardial infarction in Scotland: population based analysis. British Medical Journal 322, 1152-1153.

Marmot M \& McDowell ME (1986) Mortality decline and widening social inequalities. Lancet ii, 274-276.
Marmot M \& Wilkinson RG (2001) Psychosocial and material pathways in the relation between income and health: a response to Lynch et al. British Medical Journal 322, 1233-1236.

Marmot MG, Shipley MJ \& Rose G (1984) Inequalities in death - specific explanations of a general pattern? Lancet $\mathbf{i}$, 1003-1006.

Merlet-Benichou C, Leroy B, Gilbert T \& Lelievre-Pegorier M (1993) Retard de croissance intra-uterin et deficit en nephrons (Intrauterine growth retardation and inborn nephron deficit). M S-Medecine Sciences 9, 777-780.

Metcalfe NB \& Monaghan P (2001) Compensation for a bad start: grow now, pay later? Trends in Ecology and Evolution 16, 254-260.

Phillips DIW, Walker BR, Reynolds RM, Flanaghan DEH, Wood PJ, Osmond C, Barker DJP \& Whorwood CB (2000) Low birth weight predicts elevated plasma cortisol concentrations in adults from 3 populations. Hypertension 35, 1301-1306.

Ravelli ACJ, van der Meulen JHP, Michels RPJ, Osmond C, Barker DJP, Hales CN \& Bleker OP (1998) Glucose tolerance in adults after prenatal exposure to famine. Lancet 351, 173-177.

Rich-Edwards JW, Stampfer MJ, Manson JE, Rosner B, Hankinson SE, Colditz GA, Willett WC \& Hennekens CH (1997) Birth weight and risk of cardiovascular disease in a cohort of women followed up since 1976. British Medical Journal 315, 396-400.

Robinson R (2001) The fetal origins of adult disease. British Medical Journal 322, 375-376.

Stein CE, Fall CHD, Kumaran K, Osmond C, Cox V \& Barker DJP (1996) Fetal growth and coronary heart disease in South India. Lancet 348, 1269-1273.

West-Eberhard MJ (1989) Phenotypic plasticity and the origins of diversity. Annual Review of Ecology and Systematics 20, 249-278

Widdowson EM, Crabb DE \& Milner RDG (1972) Cellular development of some human organs before birth. Archives of Disease in Childhood 47, 652-655. 